\title{
Deoxyribonucleic Acid Base Compositions and Nucleotide Distributions of 65 Strains of Budding Bacteria
}

\author{
RAINER GEBERS,* UTA WEHMEYER, TELSE ROGGENTIN, HEINZ SCHLESNER, JUTTA KÖLBEL-BOELKE, \\ AND PETER HIRSCH \\ Institut für Allgemeine Mikrobiologie, Universität Kiel, D-2300 Kiel, Germany
}

\begin{abstract}
A total of 65 strains of appendaged or prosthecate, budding bacteria from our culture collection were selected for a study of deoxyribonucleic acid (DNA) base composition and nucleotide distribution. These strains represented 11 genera, including 4 genera of hyphal, budding bacteria which have not been formally described yet. The DNA species were thermally denatured, and absorbance-temperature profiles were recorded. The midpoints, widths, and asymmetries of the melting transitions were determined. When the DNA base compositions and nucleotide distributions were plotted on a dissimilarity map, it became evident that the strains of each genus occupied a distinct area. The distribution of strains within such an area indicated the degree of heterogeneity of a genus. When 16 Hyphomicrobium strains were analyzed, they formed five clusters within their generic area. These clusters correlated well with groups which had been previously established by DNA base composition analyses, by DNA-DNA homology studies, and by numerical taxonomy. Nine of the strains investigated were distinguished by melting profiles which were skewed uniquely to the left.
\end{abstract}

The appendaged or prosthecate, budding bacteria are a diverse group of procaryotes. These organisms may be regarded as part of the even more diverse collection of budding bacteria reviewed by Hirsch (15).

Deoxyribonucleic acid (DNA) base compositions have been reported for 8 strains of Rhodomicrobium vannielii (27), for 66 Hyphomicrobium and 2 Hyphomonas polymorpha strains (25), for 15 Prosthecomicrobium and 2 Ancalomicrobium strains (46), and for 7 strains of Pedomicrobium spp. (10). The distribution of DNA nucleotides has been determined for seven pedomicrobia (10). Genome sizes are known for only two strains, Hyphomicrobium sp. strain B-522 $\left(M_{\mathrm{r}}, 3.1 \times 10^{9}\right)(34)$ and Rhodomicrobium vannielii RM5 $\left(M_{\mathrm{r}}, 2.1 \times 10^{9}\right)(40)$. DNADNA base sequence homologies have been reported for a number of Hyphomicrobium strains and other budding bacteria (33), for Prosthecomicrobium, Ancalomicrobium, and Hyphomicrobium (35), and for Pedomicrobium species (11). Ribosomal ribonucleic acid-DNA hybridizations have been performed only between Hyphomicrobium sp. strain B-522 and various other bacteria (32).

To complete the taxonomic scheme based on analyses of the midpoints of the melting profiles $\left(T_{m}\right)$, we selected 65 representative strains from the culture collection of the Institut für Allgemeine Mikrobiologie, Kiel, Federal Republic of Germany, to study DNA base compositions and nucleotide distributions. The latter, expressed as the widths (left plus right standard deviations of compositional nucleotide distribution, $\sigma_{1}+\sigma_{\mathrm{r}}$ and asymmetries $\left(\sigma_{1} / \sigma_{\mathrm{r}}\right)$ of the guanine-plus-cytosine $(G+C)$ frequency curves $(6)$, describe an additional physicochemical quality of the bacterial genome. The DNA nucleotide distributions of some 2,500 bacterial strains were found to be "quite similar within each genus," but varied considerably between genera (6), thus providing us with routinely determined properties of the bacterial genomes which characterize genera, species, and strains.

\footnotetext{
* Corresponding author.
}

\section{MATERIALS AND METHODS}

Bacterial strains. The strain designations and the sources of isolation of the bacteria used are listed in Table 1 .

Cultivation. Most Hyphomicrobium strains, as well as strains SW-808 and T-854, were grown in medium $337+1 / 2$ (18); for strain B-522 this medium was supplemented with 2.5 $\mu \mathrm{g}$ of cyanocobalamin per liter (29). Hyphomicrobium-like strains SW-814 and SW-815 were grown in PYGV (44), which was supplemented with artificial seawater (ASW) (24). Strains SX-821 and PC-1356 and most of the Hyphomonaslike strains, as well as Prosthecomicrobium enhydrum $1187^{\mathrm{T}}$ ( $\mathrm{T}=$ type strain) and Prosthecomicrobium sp. strain SCH-1316, Pirella sp. strain SCH-1313, and Plantomyces sp. strain SCH-1317, were grown in medium $387+1 / 4$ ASW, which contained (per liter) $1 \mathrm{~g}$ of yeast extract (Difco Laboratories, Detroit, Mich.), $1 \mathrm{~g}$ of glucose, $20 \mathrm{ml}$ of Hutner basal salts (3), $250 \mathrm{ml}$ of ASW, and $50 \mathrm{ml}$ of $0.1 \mathrm{M}$ tris(hydroxymethyl)aminomethane(Tris)hydrochloride $(\mathrm{pH}$ 7.5); the final $\mathrm{pH}$ was 7.2. Strains SCH-1415, SCH-1325, and $1188^{\mathrm{T}}$, all strains of "Stella," most Pirella strains, Planctomyces maris $1190^{\mathrm{T}}$, and strain SCH-1448 were grown in PYGV supplemented with $250 \mathrm{ml}$ of ASW per liter and 50 $\mathrm{ml}$ of Tris per liter; the final $\mathrm{pH}$ was 7.2. Hyphomonas polymorpha strains PS-728 ${ }^{\mathrm{T}}$ and PR-727 and $H$. neptunium LE-670 ${ }^{\mathrm{T}}$ were cultivated in medium 383 , which contained (per liter of double-distilled water) $1 \mathrm{~g}$ of yeast extract, $1 \mathrm{~g}$ of glucose, $2 \mathrm{~g}$ of Casitone (Difco), and $1 \mathrm{~g}$ of $\mathrm{MgCl}_{2}$; the final pH was 8.0. Strains 868, 869, G-1381, ST-1307, and 1008 were grown in PYGV (44). Pedomicrobium-like strains ST-1306 and WD-1355 were grown in PSM (9). Genus T sp. strains 1128 and 1300 were grown in medium Y (8). Medium 400 , which was used for genus D sp. strains, contained (per liter) $1 \mathrm{~g}$ of peptone (Difco), $1 \mathrm{~g}$ of yeast extract, $1 \mathrm{~g}$ of glucose, $10 \mathrm{ml}$ of a vitamin solution (44), $20 \mathrm{ml}$ of Hutner basal salts, and $970 \mathrm{ml}$ of ASW $(2.5 \times$ concentrated $)$; the final $\mathrm{pH}$ was 7.5 . Strain SCH-1315 of genus $\mathrm{F}$ was grown in medium AC, which contained (per liter) $10 \mathrm{ml}$ of vitamin solution, $20 \mathrm{ml}$ of Hutner basal salts, $250 \mathrm{ml}$ of ASW, $1 \mathrm{~g}$ of sodium acetate, $1 \mathrm{~g}$ of $\mathrm{KNO}_{3}$, and $42 \mathrm{mg}$ of $\mathrm{NaH}_{2} \mathrm{PO}_{4}$; the final $\mathrm{pH}$ was 6.9. Prosthecomicrobium sp. strain $\mathrm{SCH}-1314$ 
TABLE 1. Sources of isolation and cell disintegration methods for bacterial strains

\begin{tabular}{|c|c|c|}
\hline Strain $^{a}$ & Source of isolation & $\begin{array}{c}\text { Cell } \\
\text { disintegration } \\
\text { method }^{b}\end{array}$ \\
\hline \multicolumn{3}{|l|}{ Hyphomicrobium } \\
\hline NQ-521gr $(=$ ATCC 27483) & Brackish water $(14,30)^{c}$ & Cell mill A, 10 \\
\hline $\mathrm{B}-522(=$ ATCC 27484$)$ & Soil (17) & Cell mill A, 10 \\
\hline H-526 (= ATCC 27485) & Soil (17) & Enzyme A \\
\hline MEV-533gr (= ATCC 27488) & Brackish water $(14,30)$ & Cell mill A, 10 \\
\hline F-550 & Soil (25) & Enzyme A \\
\hline I-551 (= ATCC 27489) & Soil (25) & Cell mill A, 10 \\
\hline CO-558 (= ATCC 27491) & Soil (14) & Cell mill A, 10 \\
\hline CO-559 & Soil (25) & Enzyme A \\
\hline WH-563 & Brackish water (20) & Enzyme D \\
\hline ZV-580 & Swamp soil ${ }^{d}$ & Cell mill A, 10 \\
\hline CO-582 (= ATCC 27492) & Soil $(25)$ & Enzyme A \\
\hline EA-617 & Brackish water $(20,30)$ & Enzyme A \\
\hline MC-651 (= ATCC 27497) & Soil (25) & Cell mill A, 5 \\
\hline KB-677 (= ATCC 27498) & Sewage (22) & Cell mill A, 10 \\
\hline MC-750 (= ATCC 27500) & Construction soil (25) & Cell mill A, 10 \\
\hline Wi-926 (= W54) & Freshwater pond ${ }^{\prime}$ & Enzyme D \\
\hline \multicolumn{3}{|l|}{ Hyphomicrobium-like } \\
\hline SW-808 & Seawater (14) & Cell mill A, 10 \\
\hline SW-814 & Seawater (14) & Enzyme A \\
\hline SW-815 & Seawater (14) & Enzyme A \\
\hline SX-821 & Seawater (14) & Enzyme E \\
\hline $\mathrm{T}-854(=\mathrm{T}-37)$ & Freshwater Mn deposits $(48,49)$ & Cell mill A, 10 \\
\hline PC-1356 (= PC-5) & Freshwater reservoir (47) & Enzyme A \\
\hline SCH-1415 (= Schl-37) & Brackish water $^{f}$ & Enzyme B \\
\hline \multicolumn{3}{|l|}{ Hyphomonas } \\
\hline PR-727 (= ATCC 33880) & Purulent nasal mucus (39) & Enzyme A \\
\hline PS-728 ${ }^{\mathrm{T}}\left(=\right.$ ATCC $\left.33881^{\mathrm{T}}\right)$ & Purulent nasal mucus (39) & Enzyme A \\
\hline LE-670 $\left(=14-15^{\mathrm{T}}=\operatorname{ATCC} 15444^{\mathrm{T}}\right)$ & Seawater (23) & Enzyme B \\
\hline \multicolumn{3}{|l|}{ Hyphomonas-like } \\
\hline SCH-1325 $(=$ Schl-89) & Brackish water (19) & Enzyme A \\
\hline $\mathrm{H}-1354(=\mathrm{H}-13)$ & Brackish water (51) & Enzyme E \\
\hline VP-1382 (= VP-1) & Deep sea thermal vents $(21)$ & Enzyme E \\
\hline VP-1383 (= VP-2) & Deep sea thermal vents $(21)$ & Enzyme E \\
\hline VP-1384 (= VP-3) & Deep sea thermal vents $(21)$ & Enzyme E \\
\hline VP-1385 (= VP-4) & Deep sea thermal vents $(21)$ & Enzyme E \\
\hline VP-1386 (= VP-5) & Deep sea thermal vents $(21)$ & Enzyme E \\
\hline SCH-1416 (= Schl-92) & Brackish water $^{f}$ & Enzyme E \\
\hline SCH-1417 (= Schl-135) & Brackish water $f$ & Enzyme E \\
\hline \multicolumn{3}{|l|}{ Pedomicrobium-like } \\
\hline $868(=\mathrm{Hy}-1)$ & Temporary freshwater pond ${ }^{h}$ & Enzyme A \\
\hline $869(=\mathrm{Hy}-2)$ & Temporary freshwater pond ${ }^{h}$ & Enzyme A \\
\hline ST-1306 & Freshwater reservoir (47) & Enzyme A \\
\hline WD-1355 (= WD-4) & Freshwater reservoir (47) & Cell mill A, 10 \\
\hline G-1381 (= SSED-4) & Freshwater pond ${ }^{i}$ & Cell mill A, 10 \\
\hline Rhodomicrobium sp. strain P-1093 (= P-1) & Acid forest pond (8) & Enzyme A \\
\hline \multicolumn{3}{|l|}{ Genus T } \\
\hline $1128(=\mathrm{F}-1)$ & Quartzite rock pool (8) & Enzyme A \\
\hline $1300(=\mathrm{F}-2)$ & Freshwater pond ${ }^{j}$ & Enzyme A \\
\hline ST-1307 & Freshwater reservoir (47) & Enzyme D \\
\hline \multicolumn{3}{|l|}{ Genus D } \\
\hline $954(=41 / 7)$ & Hypersaline, hyperthermal lake $(16,19)$ & Cell mill B, 5 \\
\hline $958(=41 / 2)$ & Hypersaline, hyperthermal lake $(16,19)$ & Cell mill B, 5 \\
\hline 1185 & Hypersaline, hyperthermal lake ${ }^{k}$ & Cell mill B, 5 \\
\hline Genus F sp. strain SCH-1315 (= Schl-128) & Brackish water (19) & Enzyme A \\
\hline \multicolumn{3}{|l|}{ Prosthecomicrobium } \\
\hline $1187^{\mathrm{T}}\left(=9 \mathrm{~b}^{\mathrm{T}}=\right.$ ATCC $\left.23634^{\mathrm{T}}\right)$ & Freshwater creek (44) & Detergent A \\
\hline $1188^{\mathrm{T}}\left(=3 \mathrm{a}^{\mathrm{T}}=\operatorname{ATCC} 23633^{\mathrm{T}}\right)$ & Freshwater creek (44) & Enzyme A \\
\hline SCH-1314 (= Schl-127) & Brackish water (19) & Detergent $\mathrm{A}$ \\
\hline SCH-1316 $(=$ Schl-129) & Brackish water (19) & Detergent A \\
\hline \multicolumn{3}{|l|}{ "Stella" " } \\
\hline 1203 (= VKM 1137) & Cultivated black soil (50) & Enzyme C \\
\hline SCH-1312 (= Schl-41) & Brackish water (19) & Detergent $A$ \\
\hline SCH-1320 $(=$ Schl-141) & Sewage-polluted freshwater creek ${ }^{f}$ & Detergent A \\
\hline
\end{tabular}


TABLE 1-Continued

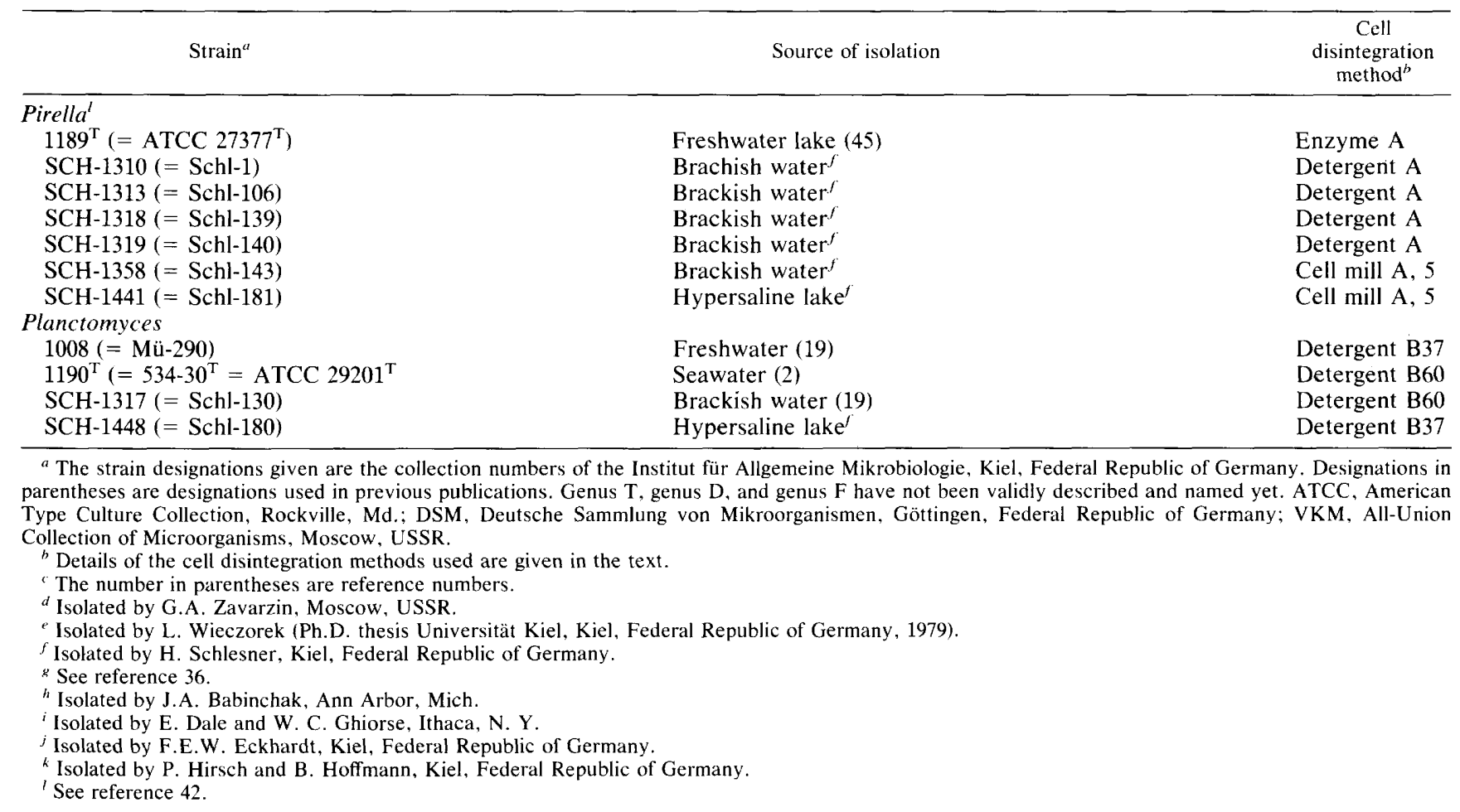

and Pirella sp. strain SCH-1319 were cultivated in PYGA, which contained (per liter) $0.15 \mathrm{~g}$ of peptone, $0.15 \mathrm{~g}$ of yeast extract, $1 \mathrm{~g}$ of glucose, $10 \mathrm{ml}$ of vitamin solution, $20 \mathrm{ml}$ of Hutner basal salts, $250 \mathrm{ml}$ of ASW, $50 \mathrm{ml}$ of Tris, and $0.25 \mathrm{~g}$ of $\left(\mathrm{NH}_{4}\right)_{2} \mathrm{SO}_{4}$; the final $\mathrm{pH}$ was 7.2. Rhodomicrobium sp. strain P-1093 was grown for 12 days anaerobically at $35^{\circ} \mathrm{C}$ in a mineral salts medium $(8,37,38)$ illuminated by 450 foot-candles $(4,844 \mathrm{~lx})(8)$. Strains 1128 and 1300 were grown in batch cultures until sedimentation of the cells occurred. The incubation temperature used for strains 954,958 , and 1185 was $43^{\circ} \mathrm{C}$; the incubation temperature used for strains $\mathrm{SCH}-1318$ and $\mathrm{SCH}-1319$ was $20^{\circ} \mathrm{C}$. All other strains were grown at $30^{\circ} \mathrm{C}$ in the dark in aerated, stirred batch cultures.

Harvesting and storage. At the end of the exponential growth phase, all cultures were checked for purity by direct microscopic examination and by plating onto solidified growth media and nutrient agar (Difco). Cells were harvested by centrifugation at $16,000 \times g$ for $20 \mathrm{~min}$ and washed twice with double-distilled water or $0.85 \%$ (wt/vol) $\mathrm{NaCl}$. Cell pellets were stored at $-20^{\circ} \mathrm{C}$ before use.

DNA preparation. Disintegration of the bacterial cell walls was achieved by various procedures (Table 1 ). The enzyme A method was a modification of a previously described procedure $(10,11)$; proteinase $\mathrm{K}(100 \mu \mathrm{g} / \mathrm{ml} ; \mathrm{E}$. Merck AG, Darmstadt,) was used instead of pronase $\mathrm{E}$. The enzyme B, enzyme $C$, and enzyme D procedures were modifications of the enzyme A method; the cell pellets were suspended not in Tris- $\mathrm{MgCl}_{2}-\mathrm{KCl}$ buffer but in $0.05 \mathrm{M}$ Tris $(\mathrm{pH} \mathrm{8)}, 0.05 \mathrm{M}$ Tris-0.05 M ethylenediaminetetraacetate (EDTA)-0.01 M $\mathrm{NaCl}(\mathrm{pH} \mathrm{8})$, and saline-EDTA (28), respectively. In the enzyme $\mathrm{E}$ method, the cells were suspended in $9.6 \mathrm{ml}$ of Tris- $\mathrm{MgCl}_{2}-\mathrm{KCl}$ buffer; then a solution containing $2 \mathrm{mg}$ of sodium dodecyl sulfate per $\mathrm{ml}$ and $1 \mathrm{mg}$ of proteinase $\mathrm{K}$ were added, and the mixture was incubated at 60 or $37^{\circ} \mathrm{C}$ for a maximum of $45 \mathrm{~min}$. Then the sodium dodecyl sulfate concentration was increased to $20 \mathrm{mg} / \mathrm{ml}$ for 5 to $15 \mathrm{~min}$ at 60 or $37^{\circ} \mathrm{C}$.

The detergent A method was adopted from Schwinghamer (43) and consisted of a detergent treatment, osmotic shock, and lysozyme treatment. The suspension buffer of the detergent B procedure was saline-EDTA; cell lysis was achieved by adding $20 \mathrm{mg}$ of sodium dodecyl sulfate per ml within 30 min at $37^{\circ} \mathrm{C}$ (detergent $\mathrm{B} 37$ method) or $60^{\circ} \mathrm{C}$ (detergent $\mathrm{B} 60$ method).

For the cell mill A disintegration procedure, 1 to $2 \mathrm{~g}$ (wet weight) of bacterial pellets was suspended in $20 \mathrm{ml}$ of saline-EDTA supplemented with $1 \mathrm{mg}$ of proteinase $\mathrm{K}$, and $50 \mathrm{~g}$ of glass beads (diameter, $0.1 \mathrm{~mm}$ ) was added (31). The mixture was precooled on ice and then shaken in an MSK cell homogenizer (Braun, Melsungen, Federal Republic of Germany) for 5 or $10 \mathrm{~s}$ (Table 1). Cell lysis was completed by adding $20 \mathrm{mg}$ of sodium dodecyl sulfate per $\mathrm{ml}$ to the suspension.

DNA was isolated from cells disrupted by an enzyme, detergent, or cell mill A treatment by a modification of the Marmur procedure (28), as follows: after $\mathrm{NaClO}_{4}$ and chloroform-i-amylalcohol were added, the suspension of lysed cells was shaken for $30 \mathrm{~min}$ (enzyme and detergent treatments) or 15 min (cell mill treatment) at 200 rpm (enzyme and detergent treatments) or $100 \mathrm{rpm}$ (cell mill treatment). Centrifugation at $27,000 \times g$ (enzyme and detergent treatments) or $1,350 \times g$ (cell mill treatment) for 20 min separated the emulsion into layers, from which the nucleic acids were precipitated and further purified by the method of Marmur. However, the length of the ribonuclease treatment was extended to $45 \mathrm{~min}$, and this treatment was followed by proteinase $\mathrm{K}(200 \mu \mathrm{g} / \mathrm{ml})$ treatment for $2 \mathrm{~h}$ at $37^{\circ} \mathrm{C}$. Subsequently, 1 volume of phenol saturated with $1 \times \mathrm{SSC}(0.15 \mathrm{M}$ 
$\mathrm{NaCl}$ plus $0.015 \mathrm{M}$ trisodium citrate, $\mathrm{pH}$ 7) and 0.1 volume of chloroform-i-amylalcohol were added to the DNA solution, and the preparation was shaken for $10 \mathrm{~min}$ at $100 \mathrm{rpm}$. Centrifugation at $27,000 \times g$ for $20 \mathrm{~min}$ separated the emulsion into three layers. From the upper layer the DNA threads were precipitated with ethanol. The precipitate was drained by mild pressure and washed three times in $0.1 \times$ SSC containing ethanol $(1: 1)$ and once for $15 \mathrm{~min}$ in diethylether. The DNA was drained and kept in the air until no ether vapor was detectable. The precipitate was dissolved in $0.1 \times$ SSC, adjusted to $1 \times \mathrm{SSC}$, and finally deproteinized by adding chloroform-i-amylalcohol. The i-propanol step was omitted. The final DNA precipitate was dissolved in sterile $0.1 \times$ SSC to a concentration between 0.5 and 1.5 $\mathrm{mg} / \mathrm{ml}$. Such solutions were stored at $-20^{\circ} \mathrm{C}$ in screw-capped tubes with 1 drop of chloroform in each cap. The concentrations and purities of DNA solutions were determined by spectrophotometry, using the following relationship: $1.0 \mathrm{U}$ of optical density at $260 \mathrm{~nm}=50 \mu \mathrm{g}$ of DNA per ml (5).

DNA extraction from genus D strains required a different treatment. Lysis by the cell mill B procedure was achieved by suspending $1 \mathrm{~g}$ (wet weight) of bacterial cells in $20 \mathrm{ml}$ of $1 \mathrm{M} \mathrm{NaCl}-0.1 \mathrm{M}$ EDTA containing $1 \mathrm{mg}$ of proteinase $\mathrm{K}$ and $1 \%$ (wt/vol) $N$-cetyl- $N, N, N$-trimethylammonium bromide (Merck), as well as $50 \mathrm{~g}$ of glass beads. The mixture was treated for $5 \mathrm{~s}$ in the cell homogenizer; this was followed by the addition of 1 volume of chloroform-i-amylalcohol and shaking at $100 \mathrm{rpm}$ for $15 \mathrm{~min}$. The resulting emulsion was centrifuged at $1,350 \times g$ for $20 \mathrm{~min}$; the upper aqueous phase was removed and mixed with 1 volume of double-distilled water. Then 0.6 volume of i-propanol was added dropwise while the solution was stirred with a glass rod. Centrifugation at $1,350 \times g$ for 10 min yielded a nucleic acid pellet which was further purified as described above.

DNA analyses. At least six thermal denaturation profiles of each DNA species investigated were recorded at $260 \mathrm{~nm}$ with a Gilford model 250 spectrophotometer, as described previously (10). From the $T_{m}$ value of these sigmoid curves the molar fraction of the DNA bases was calculated by using the following equation (26): $\mathrm{G}+\mathrm{C}$ content $=\left(T_{m}\right.$ in $0.1 \times$ $\mathrm{SSC} / 50.2)-0.990$. The melting curves were also used to determine the nucleotide distributions of the DNAs by the method of De Ley (6).

\section{RESULTS}

A large number of appendaged or prosthecate, budding bacteria have been isolated from various habitats all over the world and maintained at the Institut für Allgemeine Mikrobiologie collection. From this collection 65 representative strains were selected (Table 1), including all of the Hyphomonas, Pedomicrobium-like, genus T, genus F, and "Stella" strains.

Disintegration of the cell walls was particularly difficult with strains of Hyphomicrobium, Pedomicrobium, Rhodomicrobium, and genus D. In cases where detergent and enzyme treatments failed, the cells had to be disintegrated mechanically by using glass beads and the minimum time necessary for destroying approximately $50 \%$ of the cells. In this way, only one-half of the cell material was actually exploited; on the other hand, fragmentation of the genomes could be held to low levels, similar to the levels of DNA released by chemical disintegration procedures. Both methods, carefully used, yielded DNA fragments with $M_{\mathrm{r}}$ of $>3 \times 10^{6}$, which allowed us to record thermal denaturation profiles that were undisturbed by the fragment sizes of the molecules (4).
The purification of extracted DNAs by alternate chloroform and phenol treatments resulted in DNA preparations having ratios of absorbance at $260 \mathrm{~nm}$ to absorbance at 230 $\mathrm{nm}$ to absorbance at $280 \mathrm{~nm}$ below 1:0.490:0.520. DNA preparations from strains CO-582, SW-815, and VP-1384 gave absorbance ratios below 1:0.500:0.535.

The DNA base compositions and nucleotide distributions of the budding bacteria investigated are shown in Table 2. All strains but one had base compositions between 50 and 70 mol\% G + C; strain SCH-1415 had a G + C content of 46.3 mol\%. Within the genera themselves, the ratio varied within more or less narrow limits (e.g., Hyphomicrobium strains, 59.3 to $64.7 \mathrm{~mol} \%$ ); Hyphomonas and Hyphomonas-like bacteria, 57.5 to $60.4 \mathrm{~mol} \%$; Pedomicrobium [10] and Pedomicrobium-like strains, 62.8 to $65.7 \mathrm{~mol} \%$. The distributions of the DNA nucleotides of the budding bacteria varied considerably with respect to transition width $(6.15$ to $13.42 \mathrm{~mol} \% \mathrm{G}+\mathrm{C})$ and asymmetry $(0.90$ to 1.43$)$. However, some genera had only narrow ranges of variation. For example, for Hyphomonas and similar strains the transition ranged from width 9.23 to $10.54 \mathrm{~mol} \% \mathrm{G}+\mathrm{C}$ and the skewness ranged from 0.96 to 1.21 , for genus $\mathrm{T}$ strains the transition width ranged from 7.69 to $8.53 \mathrm{~mol} \% \mathrm{G}+\mathrm{C}$ and the skewness ranged from 0.96 to 0.99 , and for "Stella" strains the transition width ranged from 8.42 to $8.85 \mathrm{~mol} \% \mathrm{G}+\mathrm{C}$ and the skewness ranged from 0.98 to 1.15 . Other genera were more heterogeneous in this respect.

\section{DISCUSSION}

The DNA base compositions of 21 strains were determined previously by $\mathrm{CsCl}$ buoyant density centrifugation ( 2 , $25,46)$. The buoyant densities ( $\rho$ ) taken from the literature and the $T_{m}$ values of the strains determined during this study could be correlated by regression analysis with a model 67 Hewlett-Packard calculator, yielding the following linear relationship: $T_{m}$ in $0.1 \times \mathrm{SSC}=412.1(\rho-1.526)$. Previous calculations, in which $T_{m}$ and $\rho$ values of various DNA species were also used, resulted in the following equations: $T_{m}$ in $0.1 \times \mathrm{SSC}=428.5(\rho-1.533)(10) ; T_{m}$ in $0.1 \times \mathrm{SSC}=$ $489.4(\rho-1.556)(26)$; and $T_{m}$ in $1 \times \mathrm{SSC}=429.76(\rho-$ 1.5002 ) (7). Although these equations were based on data from a large number of DNA species which had been investigated in different laboratories, the relationships were similar. Therefore, we assume that a linear relationship between $\rho$ and $T_{m}$ values which is valid for all bacterial DNA species not containing unusual bases should be quite similar to the equations given above.

Since DNA nucleotide distributions and base compositions were determined by measurements which integrated the reactions of the $5 \times 10^{6}$ base pairs of an average bacterial chromosome, these characteristics must be rather conservative properties of bacteria. For example, total rearrangement (i.e., $100 \%$ transition from guanine cytosine to adenine thymine) of an average cistron $(1,500$ base pairs) would alter the base composition of the whole genome by only $0.03 \mathrm{~mol} \% \mathrm{G}+\mathrm{C}$. Additionally, many changes in the DNA sequence during divergent evolution cannot be discovered by $T_{m}$ analyses, because at least some of the transitions from gua-nine - cytosine to adenine - thymine are most likely neutralized by transitions from adenine - thymine to guanine - cytosine (or vice versa) which take place at different sites on the chromosome. However, changes in the DNA nucleotide distribution depend on the sites where base pair transitions occur, thus providing taxonomists with additional genotypic characters which change independently of compositional alterations. In our hands, width and skewness 
TABLE 2. DNA base compositions and nucleotide distributions of budding bacteria ${ }^{a}$

\begin{tabular}{|c|c|c|c|c|c|}
\hline \multirow[b]{2}{*}{ Taxon } & \multirow[b]{2}{*}{$\begin{array}{l}\text { IFAM strain } \\
\text { no. }{ }^{b}\end{array}$} & \multirow[b]{2}{*}{$\begin{array}{c}T_{n} \text { in } 0.1 \times \\
\operatorname{SSC}\left({ }^{\circ} \mathrm{C}\right)\end{array}$} & \multirow[b]{2}{*}{$\begin{array}{c}\text { Base } \\
\text { composition } \\
(\mathrm{mol} \% \mathrm{G}+\mathrm{C})^{c}\end{array}$} & \multicolumn{2}{|c|}{ Nucleotide distribution ${ }^{d}$} \\
\hline & & & & $\begin{array}{c}\text { Width } \\
\left(\sigma_{1}+\sigma_{\mathrm{r}} ;\right. \\
\text { mol\% } \%+C)\end{array}$ & $\begin{array}{c}\text { Skewness } \\
\left(\sigma_{l} / \sigma_{r}\right)\end{array}$ \\
\hline \multirow[t]{16}{*}{ Hyphomicrobium } & Wi-926 & $79.46 \pm 0.27$ & $59.29 \pm 0.54$ & $8.41 \pm 0.53$ & $1.26 \pm 0.15$ \\
\hline & B- 522 & $79.49 \pm 0.09^{\circ}$ & $59.34 \pm 0.19^{e}$ & $8.84 \pm 0.10$ & $1.21 \pm 0.07$ \\
\hline & $\mathrm{I}-551$ & $79.52 \pm 0.17$ & $59.40 \pm 0.33$ & $8.97 \pm 0.47$ & $1.11 \pm 0.04$ \\
\hline & H-526 & $79.58 \pm 0.17$ & $59.53 \pm 0.33$ & $8.87 \pm 0.17$ & $1.10 \pm 0.06$ \\
\hline & $\mathrm{CO}-558$ & $79.71 \pm 0.15$ & $59.78 \pm 0.30$ & $8.75 \pm 0.28$ & $1.09 \pm 0.04$ \\
\hline & F-550 & $79.77 \pm 0.17$ & $59.91 \pm 0.33$ & $9.17 \pm 0.19$ & $1.07 \pm 0.11$ \\
\hline & CO-559 & $79.83 \pm 0.23$ & $60.02 \pm 0.46$ & $9.69 \pm 0.25$ & $1.05 \pm 0.03$ \\
\hline & CO-582 & $80.09 \pm 0.28$ & $60.54 \pm 0.57$ & $9.46 \pm 0.21$ & $1.03 \pm 0.04$ \\
\hline & MC-750 & $80.51 \pm 0.17$ & $61.38 \pm 0.34$ & $8.67 \pm 0.08$ & $1.09 \pm 0.05$ \\
\hline & ZV-580 & $80.71 \pm 0.19$ & $61.77 \pm 0.37$ & $8.82 \pm 0.26$ & $1.20 \pm 0.02$ \\
\hline & KB-677 & $81.03 \pm 0.20$ & $62.41 \pm 0.40$ & $9.80 \pm 0.14$ & $1.15 \pm 0.04$ \\
\hline & MC-651 & $81.28 \pm 0.10$ & $62.91 \pm 0.20$ & $9.85 \pm 0.39$ & $1.21 \pm 0.05$ \\
\hline & WH-563 & $81.37 \pm 0.32$ & $63.09 \pm 0.64$ & $10.53 \pm 0.24$ & $1.25 \pm 0.10$ \\
\hline & EA-617 & $81.56 \pm 0.39$ & $63.46 \pm 0.77$ & $10.76 \pm 0.23$ & $1.18 \pm 0.06$ \\
\hline & NQ-521gr & $81.88 \pm 0.11$ & $64.11 \pm 0.22$ & $10.63 \pm 0.15$ & $1.24 \pm 0.04$ \\
\hline & MEV-533gr & $82.17 \pm 0.13$ & $64.69 \pm 0.26$ & $10.42 \pm 0.29$ & $1.21 \pm 0.12$ \\
\hline \multirow{7}{*}{ Hyphomicrobium-like } & SCH-1415 & $72.96 \pm 0.66$ & $46.34 \pm 1.32$ & $9.16 \pm 0.12$ & $1.11 \pm 0.05$ \\
\hline & SW-808 & $77.38 \pm 0.11$ & $55.15 \pm 0.21$ & $9.72 \pm 0.35$ & $1.40 \pm 0.06$ \\
\hline & $\mathrm{T}-854$ & $78.75 \pm 0.04$ & $57.88 \pm 0.15$ & $9.02 \pm 0.15$ & $1.15 \pm 0.04$ \\
\hline & SW-814 & $79.37 \pm 0.24$ & $59.11 \pm 0.48$ & $10.11 \pm 0.21$ & $1.13 \pm 0.06$ \\
\hline & SX-821 & $79.65 \pm 0.35$ & $59.66 \pm 0.70$ & $9.56 \pm 0.10$ & $1.12 \pm 0.05$ \\
\hline & SW-815 & $79.93 \pm 0.13$ & $60.23 \pm 0.26$ & $9.12 \pm 0.13$ & $1.06 \pm 0.06$ \\
\hline & PC-1356 & $82.18 \pm 0.13$ & $64.71 \pm 0.26$ & $8.41 \pm 0.35$ & $1.06 \pm 0.07$ \\
\hline \multirow[t]{3}{*}{ Hyphomonas } & PR-727 & $79.84 \pm 0.23^{e}$ & $60.05 \pm 0.47^{e}$ & $10.13 \pm 0.50$ & $1.15 \pm 0.07$ \\
\hline & PS- $728^{\mathrm{T}}$ & $79.85 \pm 0.09^{e}$ & $60.07 \pm 0.17^{\prime}$ & $10.31 \pm 0.41$ & $1.03 \pm 0.07$ \\
\hline & LE $-670^{\mathrm{T}}$ & $80.02 \pm 0.40^{e}$ & $60.40 \pm 0.80^{\circ}$ & $9.53 \pm 0.12$ & $1.08 \pm 0.05$ \\
\hline \multirow{9}{*}{ Hyphomonas-like } & VP-1386 & $78.56 \pm 0.30^{e}$ & $57.49 \pm 0.60^{\circ}$ & $9.43 \pm 0.17$ & $0.96 \pm 0.04$ \\
\hline & $\mathrm{SCH}-1416$ & $78.84 \pm 0.11$ & $58.06 \pm 0.22$ & $9.98 \pm 0.13$ & $1.10 \pm 0.07$ \\
\hline & SCH-1325 & $79.31 \pm 0.24^{e}$ & $58.98 \pm 0.47^{e}$ & $10.54 \pm 0.27$ & $1.21 \pm 0.07$ \\
\hline & H-1354 & $79.53 \pm 0.21^{e}$ & $59.42 \pm 0.42^{e}$ & $9.88 \pm 0.35$ & $1.11 \pm 0.04$ \\
\hline & VP-1384 & $79.74 \pm 0.10^{e}$ & $59.84 \pm 0.20^{\circ}$ & $9.76 \pm 0.26$ & $1.10 \pm 0.08$ \\
\hline & VP-1385 & $79.83 \pm 0.09^{\circ}$ & $60.02 \pm 0.18^{e}$ & $9.56 \pm 0.42$ & $1.07 \pm 0.04$ \\
\hline & SCH-1417 & $79.84 \pm 0.12$ & $60.05 \pm 0.23$ & $9.79 \pm 0.33$ & $1.08 \pm 0.05$ \\
\hline & VP-1382 & $79.91 \pm 0.22^{e}$ & $60.18 \pm 0.44^{e}$ & $9.57 \pm 0.61$ & $1.08 \pm 0.05$ \\
\hline & VP-1383 & $79.92 \pm 0.15^{e}$ & $60.20 \pm 0.30^{e}$ & $9.23 \pm 0.42$ & $1.09 \pm 0.05$ \\
\hline Pedomicrobium & $\mathrm{S}-1290^{\mathrm{T} f}$ & $82.46 \pm 0.19$ & $65.27 \pm 0.38$ & $9.20 \pm 0.30$ & $1.21 \pm 0.08$ \\
\hline \multirow[t]{5}{*}{ Pedomicrobium-like } & WD-1355 & $81.23 \pm 0.34$ & $62.80 \pm 0.68$ & $9.63 \pm 0.20$ & $1.29 \pm 0.08$ \\
\hline & G-1381 & $81.80 \pm 0.12$ & $63.97 \pm 0.24$ & $8.54 \pm 0.25$ & $1.09 \pm 0.07$ \\
\hline & 869 & $82.03 \pm 0.16$ & $64.41 \pm 0.33$ & $7.96 \pm 0.22$ & $1.02 \pm 0.09$ \\
\hline & 868 & $82.19 \pm 0.13$ & $64.72 \pm 0.25$ & $8.08 \pm 0.24$ & $1.09 \pm 0.12$ \\
\hline & ST-1306 & $82.33 \pm 0.19$ & $65.00 \pm 0.38$ & $8.86 \pm 0.13$ & $1.16 \pm 0.04$ \\
\hline Rhodomicrobium & P-1093 & $80.00 \pm 0.35$ & $60.36 \pm 0.71$ & $13.42 \pm 0.39$ & $1.43 \pm 0.05$ \\
\hline \multirow[t]{3}{*}{ Genus $\mathrm{T}$} & 1128 & $80.62 \pm 0.06$ & $61.60 \pm 0.11$ & $7.69 \pm 0.19$ & $0.99 \pm 0.02$ \\
\hline & ST-1307 & $80.77 \pm 0.11^{e}$ & $61.91 \pm 0.22^{e}$ & $8.28 \pm 0.19$ & $0.96 \pm 0.04$ \\
\hline & 1300 & $81.23 \pm 0.22$ & $62.82 \pm 0.43$ & $8.53 \pm 0.26$ & $0.96 \pm 0.02$ \\
\hline \multirow[t]{3}{*}{ Genus D } & 1185 & $81.18 \pm 0.10$ & $62.71 \pm 0.20$ & $8.85 \pm 0.14$ & $0.98 \pm 0.02$ \\
\hline & 958 & $81.26 \pm 0.14$ & $62.86 \pm 0.28$ & $8.58 \pm 0.40$ & $1.00 \pm 0.11$ \\
\hline & 954 & $81.61 \pm 0.27$ & $63.58 \pm 0.54$ & $8.56 \pm 0.14$ & $1.10 \pm 0.02$ \\
\hline Genus F & SCH-1315 & $80.58 \pm 0.27$ & $61.15 \pm 0.54$ & $8.24 \pm 0.30$ & $1.10 \pm 0.07$ \\
\hline \multirow[t]{4}{*}{ Prosthecomicrobium } & SCH-1314 & $81.92 \pm 0.06$ & $64.18 \pm 0.13$ & $9.62 \pm 0.07$ & $1.24 \pm 0.05$ \\
\hline & $\mathrm{SCH}-1316$ & $82.20 \pm 0.28$ & $64.75 \pm 0.56$ & $8.84 \pm 0.23$ & $0.90 \pm 0.04$ \\
\hline & $1187^{\mathrm{T}}$ & $82.28 \pm 0.30$ & $64.90 \pm 0.60$ & $8.78 \pm 0.41$ & $0.93 \pm 0.04$ \\
\hline & $1188^{\mathrm{T} f}$ & $83.84 \pm 0.14$ & $68.01 \pm 0.27$ & $10.09 \pm 0.24$ & $1.00 \pm 0.07$ \\
\hline Stella & $\mathrm{SCH}-1320$ & $83.55 \pm 0.26$ & $67.43 \pm 0.52$ & $8.85 \pm 0.41$ & $0.98 \pm 0.12$ \\
\hline & 1203 & $83.96 \pm 0.22$ & $68.25 \pm 0.44$ & $8.51 \pm 0.21$ & $1.15 \pm 0.09$ \\
\hline & SCH-1312 & $84.19 \pm 0.12$ & $68.71 \pm 0.25$ & $8.42 \pm 0.18$ & $1.05 \pm 0.03$ \\
\hline Pirella & SCH-1441 & $76.69 \pm 0.15$ & $53.77 \pm 0.30$ & $9.29 \pm 0.33$ & $1.02 \pm 0.07$ \\
\hline & $1189^{\mathrm{T}}$ & $78.02 \pm 0.20$ & $56.42 \pm 0.40$ & $8.23 \pm 0.82$ & $1.36 \pm 0.11$ \\
\hline & $\mathrm{SCH}-1310$ & $78.04 \pm 0.11$ & $56.45 \pm 0.22$ & $6.15 \pm 0.08$ & $1.04 \pm 0.05$ \\
\hline & SCH-1318 & $78.19 \pm 0.07$ & $56.75 \pm 0.14$ & $9.73 \pm 0.12$ & $1.02 \pm 0.03$ \\
\hline & SCH-1358 & $78.19 \pm 0.42$ & $56.76 \pm 0.83$ & $7.81 \pm 0.16$ & $0.98 \pm 0.09$ \\
\hline & SCH-1313 & $78.56 \pm 0.13$ & $57.49 \pm 0.26$ & $9.12 \pm 0.11$ & $1.28 \pm 0.06$ \\
\hline Pirella-like & SCH-1319 & $78.64 \pm 0.18$ & $57.65 \pm 0.36$ & $7.74 \pm 0.23$ & $1.06 \pm 0.02$ \\
\hline Planctomyces & $1190^{\mathrm{T}}$ & $75.21 \pm 0.16$ & $50.81 \pm 0.32$ & $10.93 \pm 0.06$ & $1.11 \pm 0.04$ \\
\hline
\end{tabular}


TABLE 2-Continued

\begin{tabular}{|c|c|c|c|c|c|}
\hline \multirow[b]{2}{*}{ Taxon } & \multirow[b]{2}{*}{$\begin{array}{c}\text { IFAM strain } \\
\text { no." }\end{array}$} & \multirow[b]{2}{*}{$\begin{array}{c}T_{m} \text { in } 0.1 \times \\
\operatorname{SSC}\left({ }^{\circ} \mathrm{C}\right)\end{array}$} & \multirow[b]{2}{*}{$\begin{array}{c}\text { Base } \\
\text { composition } \\
(\mathrm{mol} \% \mathrm{G}+\mathrm{C})^{r}\end{array}$} & \multicolumn{2}{|c|}{ Nucleotide distribution ${ }^{d}$} \\
\hline & & & & $\begin{array}{c}\text { Width } \\
\left(\sigma_{1}+\sigma_{r} ;\right. \\
\text { mol\% } \%+C)\end{array}$ & $\begin{array}{c}\text { Skewness } \\
\left(\sigma_{1} / \sigma_{\mathrm{r}}\right)\end{array}$ \\
\hline & SCH-1317 & $\overline{76.26 \pm 0.10}$ & $52.90 \pm 0.21$ & $11.16 \pm 0.19$ & $1.35 \pm 0.05$ \\
\hline & 1008 & $76.43 \pm 0.30$ & $53.24 \pm 0.59$ & $8.11 \pm 0.57$ & $1.01 \pm 0.06$ \\
\hline & SCH-1448 & $77.85 \pm 0.16$ & $56.08 \pm 0.33$ & $8.00 \pm 0.50$ & $0.94 \pm 0.08$ \\
\hline Escherichia & $1308^{f}$ & $76.04 \pm 0.10$ & $52.47 \pm 0.30$ & $12.71 \pm 0.24$ & $1.57 \pm 0.09$ \\
\hline Micrococcus & $\operatorname{ATCC} 381^{f}$ & $84.41 \pm 0.01$ & $69.15 \pm 0.02$ & $9.60 \pm 0.11$ & $1.03 \pm 0.04$ \\
\hline
\end{tabular}

of DNA melting profiles are valuable tools for the characterization and identification of morphologically similar bacteria with limited biochemical capabilities (e.g., hyphal, budding bacteria).

Phylogenetic distances could not be derived from the melting profiles, since convergent evolution of the physicochemical DNA characters had obviously occurred (Table 3 ). However, intrageneric heterogeneity of strains and species and differences between closely related genera could be evaluated easily by plotting DNA base compositions against the widths of the melting transitions (Fig. 1). Strains of the same genus occupied distinct areas on our dissimilarity map. In some cases the generic areas overlapped, which did not necessarily indicate a close relationship between the genera, as in the case of Pedomicrobium and Prosthecomicrobium. However, overlapping of the Hyphomicrobium and Hyphomonas areas could indeed reflect a close relationship.

The Hyphomicrobium strains formed clusters based on their DNA base compositions and nucleotide distributions (Fig. 1 and Table 4). Cluster I consisted of five isolates from mixed soil samples (strains B-522, I-551, H-526, CO-558, and F-550) and one strain from a freshwater pond (strain Wi-926). The latter strain appeared (Fig. 1) at a small distance from the others, and its DNA melting transition revealed the highest asymmetry of these strains (Table 2). However, these deviations were not significant enough to justify a separate entity.

The soil isolates of cluster I were very similar to each other and to the strains of cluster II. The cluster II strains were also isolated from soil but were isolated in the presence of carbon monoxide (25).

Strains MC-750 (cluster IIIa) and ZV-580 (IIIb) had similar DNA base compositions ( $T_{m}$ values) and melting transition widths. However, the asymmetry of the melting transitions (Table 4) and the $\rho$ values of their DNAs (25) were different. These strains were isolated from different habitats (Table 1) and are clearly distinguished by morphology and growth behavior. Therefore, it seemed likely that strains MC-750 and ZV-580 are only distantly related to each other.

The similarity of the cluster IV strains, strains KB-677 and MC-651, although these strains were isolated from different environments, was demonstrated by a previous investigation (25).

Cluster V, which contained the strains with the highest DNA base ratios (strains WH-563, EA-617, NQ-521gr, and MEV-553gr), was established because of the broad DNA melting transitions of these strains (Table 2). All of the cluster V strains came from brackish water habitats (25); strains EA-617, NQ-521gr, and MEV-533gr were subcultures of the original strain B of Mevius (30).

The results of DNA-DNA homology studies (33) correlated well with the results presented in this paper and suggested a grouping of hyphomicrobia (Table 4) similar to the clusters discussed above. Even serological relationships of Hyphomicrobium strains (41) correlated to some extent with our results. Strains belonging to cluster I (strains I-551, $\mathrm{H}-526$, and CO-558) and cluster II (strain CO-582) were serologically related to each other, whereas strain B-522 was not related to any of these strains. Strains MC-750 and ZV-580 did not show any serological relationship to one another, which confirmed the divergence of cluster III. Strains NQ-521gr and MEV-533gr of cluster V, although they were derived from one original culture, were serologically unrelated to one another or to any other strain.

Previous numerical taxonomy studies (P. Hirsch and R. R. Colwell, unpublished data) on 84 Hyphomicrobium strains led to cluster formations similar to those shown in Table 4; however, the results of the previous studies suggested that cluster I should be split into two groups (strains B-522 and $\mathrm{H}-526$ in one group and strains $\mathrm{I}-551$ and $\mathrm{CO}-558$ in the other). Strain CO-582 (cluster II) was typical of a third group. Again, the cluster III strains, strains MC-750 and ZV-580, were different. The strains of cluster IV (strains KB-677 and MC-651), like the strains of cluster V, formed a group when they were studied by numerical taxonomy.

The distinction between Hyphomicrobium-like bacteria and Hyphomonas-like bacteria is still uncertain. Most of the Hyphomicrobium strains described in the literature metabo-

TABLE 3. Convergence of DNA base compositions and nucleotide distributions ${ }^{a}$

\begin{tabular}{|c|c|c|c|c|}
\hline \multirow{2}{*}{ Examples for: } & \multirow{2}{*}{ Genus } & \multirow{2}{*}{$\begin{array}{c}\text { DNA base } \\
\text { composition } \\
(\text { mol\% } \mathrm{G}+\mathrm{C})\end{array}$} & \multicolumn{2}{|c|}{$\begin{array}{l}\text { Nucleotide } \\
\text { distribution }\end{array}$} \\
\hline & & & $\begin{array}{c}\sigma_{1}+\sigma_{\mathrm{r}} \\
(\mathrm{mol} \% \mathrm{G}+\mathrm{C})\end{array}$ & $\sigma_{\mathrm{l}} / \sigma_{\mathrm{r}}$ \\
\hline $\begin{array}{l}\text { Convergent } \\
\text { base }\end{array}$ & Corynebacterium & $54-55$ & 8.50 & 1.13 \\
\hline composition & Erwinia & $54-57$ & 10.20 & 1.33 \\
\hline $\begin{array}{l}\text { Convergent } \\
\text { nucleotide }\end{array}$ & Cytophaga & $33-40$ & 8.00 & 1.00 \\
\hline distribution & Nocardia & 70 & 8.00 & 1.00 \\
\hline
\end{tabular}

${ }^{a}$ Data from reference 6 . 


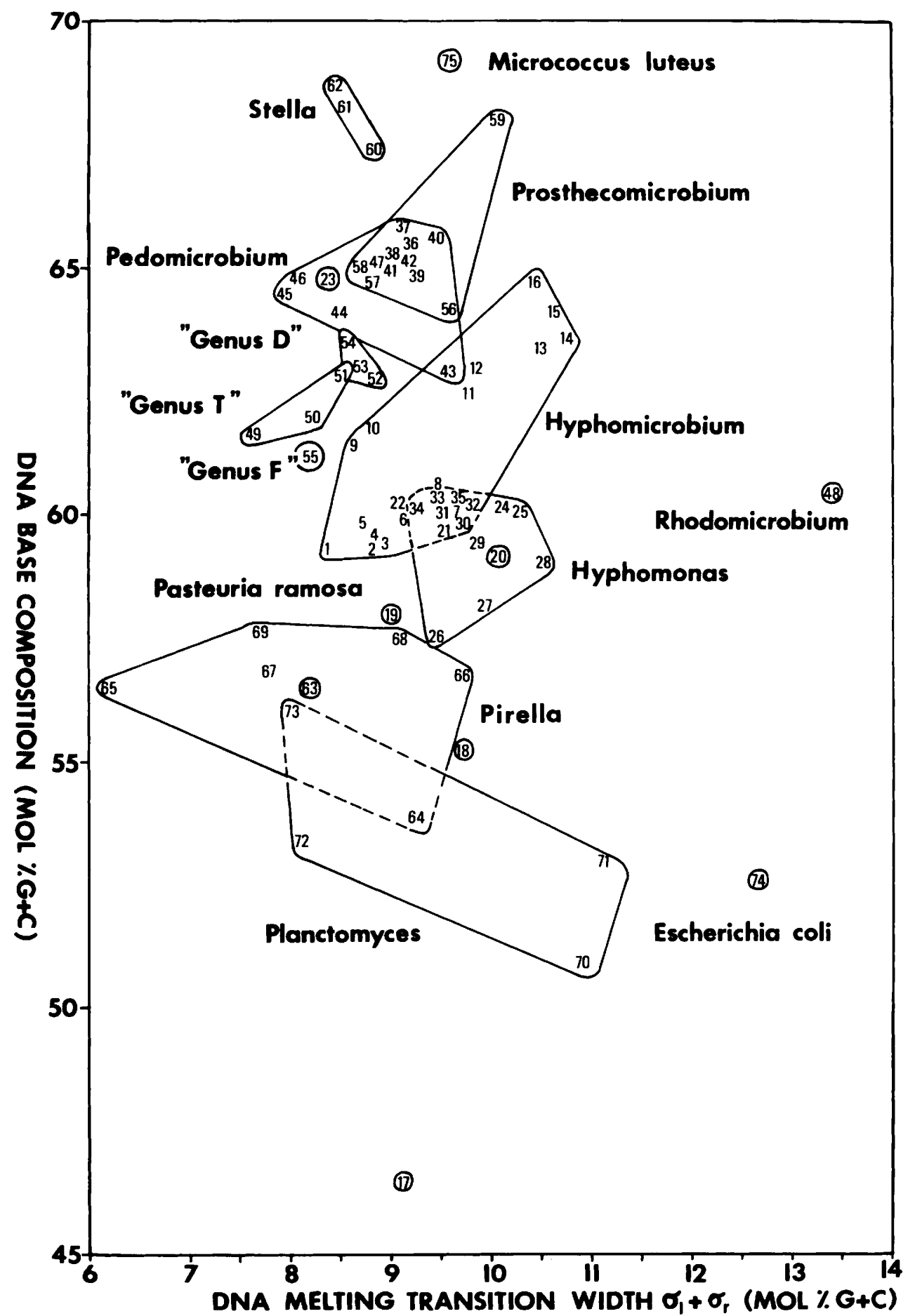

FIG. 1. Dissimilarity of budding bacteria based on their DNA base compositions and nucleotide distributions. The solid lines are generic border lines; the dashed lines indicate areas where border lines are uncertain. The numbers indicate the positions of strains, as follows: 1, strain Wi-926; 2, strain B-522; 3, strain I-551; 4, strain H-526; 5, strain CO-558; 6, strain F-550; 7, strain CO-559; 8, strain CO-582; 9, strain MC-750; 10, strain ZV-580; 11, strain KB-677; 12, strain MC-651; 13, strain WH-563; 14, strain EA-617; 15, strain NQ-521gr; 16, strain MEV-533gr; 17, strain SCH-1415; 18, strain SW-808; 19, strain T-854; 20, strain SW-814; 21, strain SX-821; 22, strain SW-815; 23, strain PC-1356; 24, strain PR-727; 25, strain PS-728 ${ }^{\mathrm{T}}$; 26, strain VP-1386; 27, strain SCH-1416; 28, strain SCH-1325; 29, strain H-1354; 30, strain VP-1384; 31, strain VP-1385; 32, strain SCH-1417; 33, strain VP-1382; 34, strain VP-1383; 35, strain LE-670 ${ }^{\mathrm{T}}$; 36, strain S-1290 $(10)$; 37, strain P-1196 (10); 38, strain Q-1197 (10); 39, strain R-1198 (10); 40, strain T-1130 (10); 41, strain F-1225 (10); 42, strain E-1129 (10); 43, strain WD-1355; 44, strain G-1381; 45, strain 869; 46, strain 868; 47, strain ST-1306; 48, strain P-1093; 49, strain 1128; 50, strain ST-1307; 51, strain 1300; 52, strain $1185 ; 53$, strain 958; 54, strain 954; 55, strain SCH-1315; 56, strain SCH-1314; 57, strain SCH-1316; 58, strain 1187 59 , strain $1188^{\mathrm{T}} ; 60$, strain SCH-1320; 61, strain 1203; 62, strain SCH-1312; 63, strain $1189^{\mathrm{T}} ; 64$, strain SCH-1441; 65, strain SCH-1310; 66, strain SCH-1318; 67, strain SCH-1358; 68, strain SCH-1313; 69, strain SCH-1319; 70, strain 1190 $;$; 71, strain SCH-1317; 72, strain 1008; 73, strain SCH-1448; 74, strain 1308; 75, strain ATCC 381. 
TABLE 4. Clustering of Hyphomicrobium strains according to DNA base composition and nucleotide distribution

\begin{tabular}{|c|c|c|c|c|c|c|}
\hline \multirow[b]{2}{*}{ Cluster } & \multirow[b]{2}{*}{ Strain } & \multirow{2}{*}{$\begin{array}{c}\text { Range of } \\
\text { DNA base } \\
\text { composition } \\
(\text { mol } \% \mathrm{G}+\mathrm{C})^{a}\end{array}$} & \multicolumn{2}{|c|}{ Range of DNA melting transition } & \multicolumn{2}{|c|}{ Clustering according to: } \\
\hline & & & $\begin{array}{c}\text { Width } \\
(\mathrm{mol} \% \mathrm{G}+\mathrm{C})^{a}\end{array}$ & Skewness $^{a}$ & $\begin{array}{l}\text { DNA base } \\
\text { composition }\end{array}$ & $\begin{array}{l}\text { DNA-DNA } \\
\text { homology }\end{array}$ \\
\hline \multirow[t]{6}{*}{ I } & Wi-926 & & & & $\mathrm{NT}^{d}$ & NT \\
\hline & B-522 & & & & Group I & Group III \\
\hline & I-551 & $59.3-59.9$ & $8.4-9.2$ & $1.07-1.26$ & Group I & NT \\
\hline & H-526 & & & & Group I & Group III \\
\hline & $\mathrm{CO}-558$ & & & & Group I & NT \\
\hline & F-550 & & & & Group I & NT \\
\hline \multirow[t]{2}{*}{ II } & CO-559 & & & & Group I & NT \\
\hline & CO-582 & $60.0-60.6$ & 9.4-9.7 & $1.03-1.05$ & Group I & NT \\
\hline III $^{a}$ & MC-750 & 61.3 & 8.6 & 1.09 & Group I & NT \\
\hline III $^{b}$ & ZV-580 & 61.8 & 8.9 & 1.20 & Group II & Group II \\
\hline \multirow[t]{2}{*}{ IV } & KB-677 & & & & Group II & Group II \\
\hline & MC-651 & $62.4-63.0$ & $9.8-9.9$ & $1.15-1.21$ & Group II & NT \\
\hline \multirow[t]{4}{*}{ V } & WH-563 & & & & Group III & Group I \\
\hline & EA-617 & & & & Group III & Group I \\
\hline & NQ-521gr & $63.0-64.7$ & $10.4-10.8$ & $1.18-1.25$ & Group III & Group I \\
\hline & MEV-533gr & & & & Group III & Group I \\
\hline
\end{tabular}

\footnotetext{
${ }^{a}$ Means of at least five determinations (see Table 2); limits of error were not taken into account

${ }^{b}$ See reference 25 .

C See reference 33

${ }^{d}$ NT, Not tested.
}

lize a limited spectrum of carbon compounds; one-carbon substrates in particular enable good growth, whereas peptides or amino acids generally allow only slow growth $(1,12$, $18,22,29)$. On the other hand, utilization of amino acids appears to be characteristic for Hyphomonas spp. $(13,39)$. Some of our strains (strains SW-814, SW-815, and SX-821) grew better on peptone- and yeast extract-containing media than on medium $337+1 / 2$ with methylamine as the sole carbon source. These bacteria were located close to the Hyphomicrobium-Hyphomonas overlapping area (Fig. 1). Further investigations must show to which genus these strains belong or whether they represent intermediate types.

The Hyphomicrobium-like strains were not incorporated into the Hyphomicrobium area (Fig. 1), because of their obvious heterogeneity. Strains SW-808, T-854, PC-1356, and SCH-1415 had similar DNA nucleotide distributions, but their DNA base ratios differed 3.4, 3.5, 6.5, and $15.0 \mathrm{~mol} \%$ $\mathrm{G}+\mathrm{C}$, respectively, from with the mean base composition of $61.35 \mathrm{~mol} \% \mathrm{G}+\mathrm{C}$ for 16 Hyphomicrobium strains. Furthermore, strain SW-808 DNA revealed a highly asymmetrical melting transition (skewness, 1.40).

Most of the Hyphomonas-like strains had very similar DNA base compositions and nucleotide distributions (Table 2), which resulted in a dense cluster close to the Hyphomicrobium area (Fig. 1). Strains VP-1386, SCH-1416, and $\mathrm{SCH}-1325$ had lower base ratios, deviating $2.5,2.0$ and $1.0 \mathrm{~mol} \% \mathrm{G}+\mathrm{C}$, respectively, from the average $(60.02 \mathrm{~mol} \%$ $\mathrm{G}+\mathrm{C}$ ) of the seven remaining strains. However, these differences were too small to justify exclusion of these bacteria from the Hyphomonas area; it seemed more likely that the three strains represent different species.

Previously investigated Pedomicrobium spp. (10) formed a dense cluster with narrow limits (Fig. 1). The Pedomicrobium-like strains which we studied deviated more or less from this main cluster. The low DNA base composition of strain WD-1355 caused its positioning close to Hyphomicrobium strains KB-677 and MC-651. Since there was no evidence of any phenotypic similarity between strain WD-1355 and these hyphomicrobia, a close relationship was doubtful. Since all of the Pedomicrobium-like strains exhib- ited morphological characters and deposition of heavy metal oxides typical of Pedomicrobium (9), these strains probably represent new species of this genus.

The remaining genera of hyphal, budding bacteria, Rhodomicrobium, genus $\mathrm{T}$, genus $\mathrm{D}$, and genus $\mathrm{F}$, were represented in this study by only one or three strains each. The respective strains of genus $\mathrm{T}$ and genus $\mathrm{D}$ revealed high levels of similarity in their DNA properties (Table 2 and Fig. 1 ), which confirmed the preliminary classification of these taxa as new genera.

The Prosthecomicrobium DNAs showed considerable heterogeneity (Table 2). Prosthecomicrobium enhydrum $1187^{\mathrm{T}}$ and Prosthecomicrobium pneumaticum $1188^{\mathrm{T}}$ were scattered on the dissimilarity map (Fig. 1), suggesting that they are distantly related. This was in agreement with previous investigations on DNA base compositions (46) and DNADNA homologies (35) in which the authors emphasized the diversity of Prosthecomicrobium and suggested creation of new species. Since strain SCH-1314 differed from the other prosthecomicrobia in all DNA properties (Table 2), it also may represent a new species; detailed taxonomic studies are indicated. Strain SCH-1316, on the other hand, was very similar in all respects to Prosthecomicrobium enhydrum $1187^{\mathrm{T}}$ (Table 2 and Fig. 1).

"Stella humosa" 1203 and two additional strains, strains SCH-1320 and SCH-1312, were similar to each other, confirming the preliminary classification of this genus based on morphological characters.

Strains of Pirella revealed considerable diversity based on their DNA nucleotide distributions (Table 2). However, their DNA base compositions varied only within $1.3 \mathrm{~mol} \% \mathrm{G}+\mathrm{C}$. The heterogeneity of this group of budding bacteria is presently being investigated.

The four strains collected as Planctomyces spp., including Planctomyces maris $1190^{\mathrm{T}}$, differed widely in many respects (Table 2). Considerable distances between the positions of these strains (Fig. 1) suggested that each of them represents a different Planctomyces species or even a separate genus.

It should be emphasized that all strains of genus $\mathrm{T}$, strain 1185 of genus D, and Hyphomonas sp. strain VP-1386, as 
well as Prosthecomicrobium spp. strains SCH-1316 and $1187^{\mathrm{T}}$, "Stella" sp. strain SCH-1320, and Planctomyces sp. strain SCH-1448, were distinguished by melting transition asymmetry ratios below 1.0 (Table 2). All other DNA species investigated in this study had symmetrical melting profiles $\left(\sigma_{l} / \sigma_{\mathrm{r}}, 1.0\right)$ or had asymmetry ratios higher than 1.0 . According to the investigations of De Ley (6) on 2,500 different strains, the asymmetry ratios of bacterial DNAs range from 1.0 to 1.6 , with an average of 1.33 . The average ratio of our 65 prosthecate, budding bacterial strains was 1.11 ; the range of variation was 0.90 to 1.43 . Melting profiles skewed to the left $\left(\sigma_{1} / \sigma_{\mathrm{r}},<1.0\right)$ have not been reported previously.

The excellent correlation of the two-dimensional combination of physicochemical properties of bacterial DNAs with DNA-DNA homologies and with numerical taxonomy underlined the suitability of this procedure for bacterial taxonomy. One further advantage of this method was the availability of three different DNA characters (i.e., melting point and width and skewness of melting transition) from only one experiment (i.e., thermally controlled denaturation).

\section{ACKNOWLEDGMENTS}

We gratefully acknowledge the donation of strains by F. E. W. Eckhardt, Kiel, Federal Republic of Germany; W. C. Ghiorse, Ithaca, N.Y.; R. L. Moore, Calgary, Alberta, Canada; J. S. Poindexter, New York, N.Y.; P. Roggentin, Kiel, Federal Republic of Germany; and J. T. Staley, Seattle, Wash.

Part of this work was supported by a grant from the Deutsche Forschungsgemeinschaft, Bonn-Bad Godesberg, Federal Republic of Germany, to P.H.

\section{LITERATURE CITED}

1. Attwood, M. M., and W. Harder. 1973. The metabolism of organic carbon compounds in hyphomicrobia: metabolism of $\mathrm{C}_{2}$ compounds. Antonie van Leeuwenhoek J. Microbiol. Serol. 39:357.

2. Bauld, J., and J. T. Staley. 1976. Planctomyces maris sp. nov.: a marine isolate of the Planctomyces-Blastocaulis group of budding bacteria. J. Gen. Microbiol. 97:45-55.

3. Cohen-Bazire, G., W. R. Sistrom, and R. Y. Stanier. 1957. Kinetic studies of pigment synthesis by nonsulfur purple bacteria. J. Cell. Comp. Physiol. 49:25-68.

4. Crothers, D. M., N. R. Kallenbach, and B. H. Zimm. 1965. The melting transition of low molecular-weight DNA: theory and experiment. J. Mol. Biol. 11:802-820.

5. Cryer, D. R., R. Eccleshall, and J. Marmur. 1975. Isolation of yeast DNA. Methods Cell Biol. 12:39-44

6. De Ley, J. 1969. Compositional nucleotide distribution and the theoretical prediction of homology in bacterial DNA. J. Theor. Biol. 22:89-116.

7. De Ley, J. 1970. Reexamination of the association between melting point, buoyant density and chemical base composition of deoxyribonucleic acid. J. Bacteriol. 101:738-754.

8. Eckhardt, F. E. W., P. Roggentin, and P. Hirsch. 1979. Fatty acid composition of various hyphal budding bacteria. Arch. Microbiol. 120:81-85.

9. Gebers, R. 1981. Enrichment, isolation, and emended description of Pedomicrobium ferrugineum Aristovskaya and Pedomicrobium manganicum Aristovskaya. Int. J. Syst. Bacteriol. 31:302-316.

10. Gebers, R., M. Mandel, and P. Hirsch. 1981. Deoxyribonucleic acid base composition and nucleotide distribution of Pedomicrobium spp. Zentralbl. Bakteriol. Parasitenkd. Infektionskr. Hyg. Abt. 1 Orig. Reihe C 2:332-338.

11. Gebers, R., R. L. Moore, and P. Hirsch. 1981. DNA/DNA reassociation studies on the genus Pedomicrobium. FEMS Microbiol. Lett. 11:283-286.

11a.Gebers, R., R. L. Moore, and P. Hirsch. 1984. Physiological properties and DNA-DNA homologies of Hyphomonas polymorpha and Hyphomonas neptunium. Syst. Appl. Microbiol. 5:510-517.

12. Harder, W., and M. M. Attwood. 1973. The metabolism of organic carbon compounds in hyphomicrobia: pathway of carbon assimilation during growth on methanol. Antonie van Leeuwenhoek J. Microbiol. Serol, 39:358.

13. Havenner, J. A., B. A. McCardell, and R. M. Weiner. 1979. Development of defined, minimal, and complete media for the growth of Hyphomicrobium neptunium. Appl. Environ. Microbiol. 38:18-23.

14. Hirsch, P. 1968. Biology of budding bacteria. IV. Epicellular deposition of iron by aquatic budding bacteria. Arch. Mikrobiol. 60:201-216.

15. Hirsch, P. 1974. Budding bacteria. Annu. Rev. Microbiol. 28:391-444.

16. Hirsch, P. 1980. Distribution and pure culture studies of morphologically distinct solar lake microorganisms, p. 41-60. In A. Nissenbaum (ed.), Hypersaline brines and evaporitic environments. Elsevier/North-Holland Scientific Publishing Co., Amsterdam.

17. Hirsch, P., and S. F. Conti. 1964. Biology of budding bacteria. I. Enrichment, isolation and morphology of Hyphomicrobium spp. Arch. Mikrobiol. 48:339-357.

18. Hirsch, P., and S. F. Conti. 1964. Biology of budding bacteria. II. Growth and nutrition of Hyphomicrobium spp. Arch. Mikrobiol. 48:358-367.

19. Hirsch, P., M. Müller, and H. Schlesner. 1977. New aquatic budding and prosthecate bacteria and their taxonomic position. Soc. Appl. Bacteriol. Symp. Ser. 6:107-133.

20. Hirsch, P., and G. Rheinheimer. 1968. Biology of budding bacteria. V. Budding bacteria in aquatic habitats: occurrence, enrichment and isolation. Arch. Mikrobiol. 62:289-306.

21. Jannasch, H. W., and C. O. Wirsen. 1981. Morphological survey of microbial mats near deep-sea thermal vents. Appl. Environ. Microbiol. 41:528-538.

22. Kingma-Boltjes, T. Y. 1936. Uber Hyphomicrobium vulgare Stutzer et Hartleb. Arch. Mikrobiol. 7:188-205.

23. Leifson, E. 1964. Hyphomicrobium neptunium sp. n. Antonie van Leeuwenhoek J. Microbiol. Serol. 30:249-256.

24. Lyman, J., and R. H. Fleming. 1940. Composition of seawater. J. Mar. Res. 3:134-146.

25. Mandel, M., P. Hirsch, and S. F. Conti. 1972. Deoxyribonucleic acid base compositions of hyphomicrobia. Arch. Mikrobiol. 81:289-294.

26. Mandel, M., L. Igambi, J. Bergendahl, M. L. Dodsen, Jr., and E. Scheltgen. 1970. Correlation of melting temperature and cesium chloride buoyant density of bacterial deoxyribonucleic acid. $\mathbf{J}$. Bacteriol. 101:333-338.

27. Mandel, M., E. R. Leadbetter, N. Pfennig, and H. G. Trüper. 1971. Deoxyribonucleic acid base compositions of phototrophic bacteria. Int. J. Syst. Bacteriol. 21:222-230.

28. Marmur, J. 1961. A procedure for the isolation of deoxyribonucleic acid from micro-organisms. J. Mol. Biol. 3:208-218.

29. Matzen, N., and P. Hirsch. 1982. Improved growth conditions for Hyphomicrobium sp. B-522 and two additional strains. Arch. Microbiol. 131:32-35.

30. Mevius, W., Jr. 1953. Beiträge zur Kenntnis von Hyphomicrobium vulgare Stutzer et Hartleb. Arch. Mikrobiol. 19:1-29.

31. Meyer, S. A., and K. H. Schleifer. 1975. Rapid procedure for the approximate determination of the deoxyribonucleic acid base composition of micrococci, staphylococci, and other bacteria. Int. J. Syst. Bacteriol. 25:383-385.

32. Moore, R. L. 1977. Ribosomal ribonucleic acid cistron homologies among Hyphomicrobium and various other bacteria. Can. J. Microbiol. 23:478-481.

33. Moore, R. L., and P. Hirsch. 1972. Deoxyribonucleic acid base sequence homologies of some budding and prosthecate bacteria. J. Bacteriol. 110:256-261.

34. Moore, R. L., and P. Hirsch. 1973. Nuclear apparatus of Hyphomicrobium. J. Bacteriol. 116:1447-1455.

35. Moore, R. L., and J. T. Staley. 1976. Deoxyribonucleic acid homology of Prosthecomicrobium and Ancalomicrobium 
strains. Int. J. Syst. Bacteriol. 26:283-285.

36. Moore, R. L., R. M. Weiner, and R. Gebers. 1984. Genus Hyphomonas Pongratz 1957 nom. rev. emend., Hyphomonas polymorpha Pongratz 1957 nom. rev. emend., and Hyphomonas neptunium (Leifson 1964) comb. nov. emend. (Hyphomicrobium neptunium). Int. J. Syst. Bacteriol. 34:71-73.

37. Pfennig, N. 1965. Anreicherungskulturen für rote und grüne Schwefelbakterien. Zentralbl. Bakteriol. Parasitenkd. Infektionskr. Hyg. Abt. 1 Suppl. 1:179-189, 503-504.

38. Pfennig, N. 1969. Rhodopseudomonas acidophila sp. n., a new species of the budding purple nonsulfur bacteria. J. Bacteriol. 99:597-602.

39. Pongratz, E. 1957. D'une bactérie pédiculée isolée d'un pus de sinus. Schweiz. Z. Pathol. Bakteriol. 20:593-608.

40. Potts, L. E., C. S. Dow, and R. J. Avery. 1980. The genome of Rhodomicrobium vannielii, a polymorphic prosthecate bacterium. J. Gen. Microbiol. 117:501-507.

41. Powell, D. M., B. S. Roberson, and R. M. Weiner. 1980. Serological relationships among budding, prosthecate bacteria. Can. J. Microbiol. 26:209-217.

42. Schlesner, H., and P. Hirsch. 1984. Assignment of ATCC 27377 to Pirella gen. nov. as Pirella staleyi comb. nov. Int. J. Syst. Bacteriol. 34:492-495.

43. Schwinghamer, E. A. 1980. A method for improved lysis of some
Gram-negative bacteria. FEMS Microbiol. Lett. 7:157-162.

44. Staley, J. T. 1968. Prosthecomicrobium and Ancalomicrobium: new freshwater prosthecate bacteria. J. Bacteriol. 95: 1921-1942.

45. Staley, J. T. 1973. Budding bacteria of the Pasteuria-Blastobacter group. Can. J. Microbiol. 19:609-614.

46. Staley, J. T., and M. Mandel. 1973. Deoxyribonucleic acid base composition of Prosthecomicrobium and Ancalomicrobium strains. Int. J. Syst. Bacteriol. 23:271-273.

47. Staley, J. T., K. C. Marshall, and V. B. D. Skerman. 1980. Budding and prosthecate bacteria from freshwater habitats of various trophic states. Microb. Ecol. 5:245-251.

48. Tyler, P. A., and K. C. Marshall. 1967. Pleomorphy in stalked, budding bacteria. J. Bacteriol. 93:1132-1136.

49. Tyler, P. A., and K. C. Marshall. 1967. Microbial oxidation of manganese in hydro-electric pipelines. Antonie van Leeuwenhoek J. Microbiol. Serol. 33:171-183.

50. Vasil'eva, L. V. 1970. Ein sternförmiger Boden-Mikroorganismus. Izv. Akad. Nauk SSSR Ser. Biol. 2:308-310. (Translated from Russian.)

51. Weiner, R. M., D. Hussong, and R. R. Colwell. 1980. An estuarine agar medium for enumeration of aerobic heterotrophic bacteria associated with water, sediment, and shellfish. Can. J. Microbiol. 26:1366-1369. 